\title{
LA DIALÉCTICA EN EL CANCIONERO DE BAENA
}

\author{
María José Gómez Sánchez-Romate \\ Universidad Complutense de Madrid
}

Los hombres medievales son ante todo creyentes. Para ellos la fe es un tamiz por el que han de pasar todas las demás actividades, es una omnipresencia que intenta encauzar el mundo. Por ello, disciplinas en principio contradictorias, o al menos de distinta concepción, como son la filosofía y la teología, se confunden; en una indistinción que proviene ya de la cristianización o moralización de los filósofos antiguos, y se desarrolla en la filosofía medieval como un intento de aunar razón y revelación:

Desde los orígenes patrísticos hasta fines del siglo XIV, la historia del pensamiento cristiano es la de un esfuerzo incesantemente renovado para manifestar la conformidad entre la razón natural y la fe, cuando esa conformidad existe, y para lograrla, cuando no existe. ${ }^{1}$

La Escolástica, en su propósito de dar un fundamento racional a la dogmática cristiana, impondrá en las escuelas catedralicias y universidades el estudio de las siete artes liberales, entre las que se encuentra, dentro del trivium, la dialéctica:

Et las tres artes del trivio como dixiemos ensenna a omne seer bien razonado, et las quatro del quadruvio le fazen sabio. ${ }^{2}$

La dialetica es art pora saber connoscer si a verdad o mentira en la razon quela gramatica compuso, e saber departir la una dela otra; mas que por que esto non se puede fazer menos de dos, ell uno que demande et ell otro que responda, pusieron le nombre dialetica que muestra tanto como razonamiento de dos por fallar la verdad complida mientre. ${ }^{3}$

1 Gilson, E., La filosofía en la Edad Media, Gredos, Madrid, 1985, p. 697.

2 Alfonso X el Sabio, Prosa histórica. Ed. Benito Brancaforte, Cátedra, Madrid, 1984, p. 153.

3 Ibidem, p. 150. 
Los profesores, por tanto, emplean el diálogo como medio para ejercitar la memoria y como un adiestramiento dialéctico que instruya la capacidad de raciocinio, incluso Beda recomienda la forma de pregunta y respuesta para la enseñanza. Así, «la Escolástica medieval estaba amenazada desde un principio por un peligro interno(...): racionalismo». ${ }^{4}$

La dialéctica, nacida como un estudio del raciocinio y sus leyes, sus formas y modos de expresión, como un método de refutación, fue ya utilizado por los sofistas como arma pragmática para vencer en las disputas. Y es esta posible doble untilización de análisis y lucha lo que motivo las múltiples discusiones medievales sobre la legitimidad de su aplicación a las cosas divinas.

Ya en el siglo XI, y debido al ataque de casi todos los dogmas en nombre de una dialéctica que se aprendía en el comentario de Mario Victorino al De inventione de Cicerón, se distinguió su doble papel, siendo el de simple arte de la discusión el que reprobaban los adversarios de quienes practicaban este uso, considerando que con sus opiniones pretendían limitar la potencia divina. ${ }^{5}$

Durante el siglo XII el enfrentamiento se recrudece, por una parte, porque al comenzar la emancipación de las artes profanas, el gusto de la dialéctica por la dialéctica se hace más vivo, e inquietante su aplicación al dogma; y por otra, por el desarrollo de las escuelas urbanas -capitulares o catedralicias-, que propugnaban una fe razonada, frente a las escuelas monásticas, con su ideal de recogimiento y vuelta a la simplicidad del Evangelio. Las discusiones entre Abelardo y San Bernardo son el claro exponente de estas dos visiones de la fe.

Lo cierto es que «aunque hubo autores que propugnaban la aplicación de reglas lógicas de inferencia a los problemas del dogma religioso, la mayoría se oponían a ello», ${ }^{6}$ como por ejemplo San Pedro Damián. La filosofía comenzaba a exigir su espacio, mientras los libros de sentencias y las Sumas teológicas pretendían encerrar el mundo en unas leyes inamovibles.

La transformación que sufre el siglo XIII debido a la creación de las universidades, el descubrimiento de Aristóteles y la toma de contacto con los fịlósofos árabes y judíos, no supone un gran cambio con respecto a la pujanza de la racionalidad. Esta seguirá desarrollándose en los círculos universitarios, de manera que en el año 1277 se producirá una condena eclesiástica de 219 principios filosófico-teológicos en París y Oxford, como instancia de autoridad que cuida y transmite el sentido de la Revelación.

Esta circunstancia tuvo necesariamente que perturbar la vida universitaria, que de polémica fértil vería su actividad reducida a estéril discusión. ${ }^{7}$

Así, el siglo XIV, en medio de una crisis socio-política que agudizaría su posición crítica y traería el germen del mundo moderno, recoge, por una parte, una Escolástica en decadencia:

4 Pieper, J., Filosofía medieval y mundo moderno, Rialp, Madrid, 1973, p. 53.

5 Bréhier, E., La filosofía en la Edad Media, Uteha, México, 1959, p. 85.

6 Weinberg, J., Breve historia de la filosofía medieval, Cátedra, Madrid, 1987.

7 Pieper, J., O. C., p. 163. 
La exposición doctrinal, acompañada de demostración, retrocede cada vez más ante la cuestión que pone frente a frente a un preguntante y a un respondiente. Todo ejercicio del espíritu que no sea el recogimiento místico es una justa, ${ }^{8}$

y por otra, el convencimiento de que era ya imposible seguir subordinando la filosofía a la teología, que era necesario racionalizar las cuestiones de carácter teológico.

En estas condiciones, se cuestionan como probables proposiciones teológicas hasta entonces consideradas indudables, y proposiciones contrarias a la teología como método de invalidación. Procedimiento que, insensiblemente, va abriendo una brecha entre la razón y la fe, habiéndose quejado ya Santo Tomás de que «so pretexto de recitar las teorías subversivas para combatirlas, se argumentase demasiado en su favor».?

Ese criticismo socavó las bases de la Escolástica, y se expandió, desbordado, por los campos de la ciencia, la literatura y el arte.

De este modo, y amparados por una tradición de poesía de debate que en la literatura castellana se inicia en el siglo XIII, surge en el siglo XV una nueva concepción de la poesía culta en la que no sólo el dominio técnico es la finalidad de la obra, sino también la demostración de los conocimientos adquiridos por estudio. De algún modo, «la ciencia poética es considerada una especie de filosofía ${ }^{10}$ que comienza a cuestionarse problemas teológicos y filosóficos al tiempo que amorosos y retóricos, mientras sus autores toman conciencia de su propio saber y del vehículo que el poema puede representar en sus indagaciones:

Los quales usades del arte gayosa,

filósofos, teólogos, de alta exçelencia, astrólogos, médicos de muy grand prudençia, e todos los otros en quien amor possa; a vuestra presençia notable, famosa

fago pregunta por ser avisado

del vuestro saber perfecto, esmerado

e grand discreçión atan valiosa. ${ }^{11}$

Casi todos estos escritores tienen una formación parecida dentro de la Escolástica y el tomismo, y son expertos en las ciencias de las que tratan, lo cual dejan patente tanto en las rúbricas iniciales:

(...) comiénçase aqui una quistión qu'el ovo con Fray Lope del Monte, bachiller en theología, ${ }^{12}$

como en las múltiples referencias a teorías filosóficas o sermones de los Papas.

8 Bréhier, E., O. C., p. 272.

9 Ibidem, p. 273.

10 Labrador, José J., Poesía didáctica medieval: la pregunta en el cancionero de Baena, Maisal, Madrid, 1974, p. 15.

11 Cancionero de Baena, CSIC, Madrid, 1966, pp. 770-771.

12 Ibidem, p. 701. 
La filosofía es más profunda en unos que en otros autores, sus planteamientos y recursos retóricos más sutiles y precisos según el genio del escritor, pero en todos ellos preside la razón discursiva, la especulación intelectual para el esclarecimiento del dogma o para debatir la cuestión más liviana. La discusión, de nuevo, se conviente en camino de conocimiento y «su pensamiento cuaja en los moldes del silogismo y se expresan a través de dura disciplina retórica estrechamente relacionada con la dialéctica».13

Para este fin, hace su aparición la pregunta y respuesta, con origen en Provenza y antecedente literario directo en la tençó gallego-portuguesa, con la salvedad de que lo que fue una distracción o juego intrascentente y evasivo, ahora, por su temática, funciona como un medio para expresar sus disquisiciones. Aunque no se halle exento de un componente lúdico y provocativo en su planteamiento:

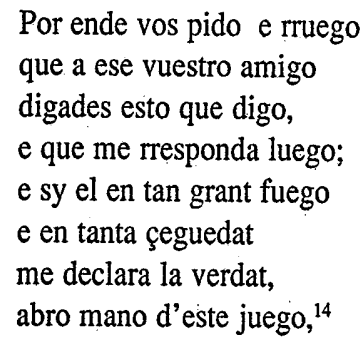

lo cierto es que éste se encuentra más cercano a las disputas dialécticas, como reto en el planteamiento lógico, que a las triviales discusiones de otros poetas cortesanos, no ajenos al uso de las reglas lógicas pero distantes de una profundidad de pensamiento, sacrificándolo todo al virtuosismo retórico y el lucimiento personal.

Se trata ahora de un debate real, que requiere dos autores reales y una intención de entablarlo: el primero guiado por el deseo de aprender o por curiosidad, y el segundo llevado del deseo de esclarecer las dudas del preguntante, que escribió la pregunta con la intención explícita de recibir contestación.

$\mathrm{La}$ arquitectura retórica que sustenta este tipo de poesía dentro del Cancionero de Baena se compone, según José J. Labrador, de cuatro partes recurrentes: la primera de ellas, las fórmulas de cortesía, con los saludos, los tratamientos, la despedida y los enlaces interiores que refuerzan la relación personal establecida; la segunda, la captatio benevolentiae, tópico literario consistente en la alabanza ajena y el menosprecio propio, en un intento de granjearse las simpatías del lector $\mathrm{u}$ oyente; la tercera consiste en la pregunta en sí, que puede desarrollarse de tres modos, directamente, primero el argumento y luego la pregunta, o al revés; $y$, por último, la cuarta sería la insistencia, 0 deseo repetidamente expresado de recibir una respuesta. ${ }^{15}$

13 Labrador, J.J., O. C., p. 80 .

14 Cancionero de Baena, O. C., p. 703.

15 Labrador, J.J., O. C., p. 49. 
Apoyatura del espíritu crítico e investigador que domina el siglo, y del que no se ven libres las cuestiones teológicas. La fuerte crisis religiosa del momento, con el Cisma de Occidente en plena vigencia, trae como consecuencia un deterioro de la devoción cristiana, comenzando a discutirse el poder temporal y espiritual del papado y revisándose todos los postulados teológicos tradicionales: la Trinidad, la Eucaristía, la Virgen María y la predestinación. ${ }^{16}$

Llevados de su afán racionalizador, surgen las cuestiones más insospechadas, lindando en ocasiones con la heterodoxia. Así, y en parte siguiendo un célebre argumento retórico extraído del De inventione de Cicerón: si peperit, cum viro concubuit (si ha dado a luz, cohabitó con un hombre):
Señor, nos avemos que muger casada que tenga marido, maguera cuytado, que biva con el muy desconsolada sy quier tomar otro que fase pecado; e yo sobre esto tengo maginado que non fas pecado ni comete error, pues que lo fiso Dios Nuestro Señor al santo Joseh que era desposado. (...) e pues plogo a Dios e fue su mesura de faser su Fijo en muger ajena, non me paresçe que meresçè pena el que en tal pecca en toda fygura. ${ }^{17}$

Escollo que, a pesar de ser salvado mediante la referencia a la concepción espiritual y no carnal de la Virgen, nos prueba hasta qué punto la libertad de opinión era posible. Independencia debida a la indubitabilidad y cotidianeidad del dogma en la vivencia de la religión, que toleraba hasta la burla sin perder la ortodoxia -caso de algunos pasajes del Libro de Buen Amor del Arcipreste de Hita-, puesto que hasta la irrupción del protestantismo y la Reforma, momento en que se exigirá una ortodoxia militante sin fisuras como baluarte contra opiniones consideradas heréticas y desviadas, la familiaridad con los elementos religiosos permitía ciertas licencias.

En esta época incierta, que presagia un tiempo nuevo, se exponen, por un deseo de indagar, una serie de actitudes que cuajarán en algunas ideas protestantes, pero se hace sin conciencia de desviación, con el único propósito de encontrar fundamentos lógicos a su fe y desde la plena conciencia de su religiosidad.

La dialéctica salta a la literatura o la literatura se convierte en vía transitable para la dialéctica, en parte por tratarse de un hábito mental adquirido con la Escolástica, y en parte por la fuerza de una razón cada vez menos conformista y que había elegido por campo de batalla, desde el principio, las irrefrenables dudas con las que se enfrentaba el hombre.

16 Ibidem, p. 92.

17 Cancionero de Baena, O. C., p. 964. 
Los poetas, como hombres de su tiempo, llevan a sus versos la problemática que les tocó vivir, y lo hacen desde la dialéctica porque ella permite la confrontación de ideas, al tiempo que la comunicación entre miembros de una misma generación que manifiestan unas inquietudes comunes, porque ella es la puerta del siglo que se presagia como un renacimiento de las capacidades del hombre.

Un enfrentamiento lógico, un método de análisis y una espuela de futuro, todo ello es la dialéctica para los poetas de un siglo que perdía la fe en sí mismo. Y además, cómo no, un instrumento poético. 